\title{
Experimental Study on the Mechanical Properties of Coal Seam as a Main Aquifer of Xiaojihan Coal Mine
}

\author{
Jingna Guo ${ }^{1}$, Qiang $\mathrm{Li}^{1}$, Shun-cai $\mathrm{Li}^{2}$ \\ ${ }^{I}$ State Key Laboratory for Geo-mechanics and Deep Underground Engineering, China University of Mining and \\ Technology, Xuzhou Jiangsu 221008, China \\ ${ }^{2}$ School of Mechanical and Electrical Engineering, Jiangsu Normal University, Xuzhou 221116, China
}

*Corresponding Author: Jingna Guo, State Key Laboratory for Geo-mechanics and Deep Underground Engineering, China University of Mining and Technology, Xuzhou Jiangsu 221008, China

\begin{abstract}
Usually the aquifer is above or below the coal seam, for the first time, the mining coal seam is found as the main aquifer in Xiaojihan Coal Mine of China's western Yuheng Mining Area. In this paper, we studied the mechanical properties of the water bearing coal seam in Xiaojihan Coal Mine. Based on the study of strength characteristics of water bearing coal seam, its special mechanical characteristics which are different from the other seams are obtained. Through uniaxial compression test, triaxial compression test and split test, the parameters such as the compressive strength, elastic modulus, Poisson rate, tensile strength and internal friction angle of each rock stratum are obtained. The research shows that the tensile strength and internal friction angle of the coal specimens from the water bearing coal seam are lower than that from the other rock strata. These mechanical properties indicate that the structure of coal seam is loose and it contains a large number of pores and has good permeability. Therefore the coal seams of Xiaojihan Mine Coal posses the aquifer condition. The obtained mechanical properties provided a reliable theoretical basis for forecasting mining face and mine water inflow, for establishing the early pre-warning system of mine water disaster, for designing and optimizing the technology of driving and coal mining related with water disaster prevention.
\end{abstract}

Keywords: Xiaojihan Coal Mine, main aquifer, mechanical properties, experimental study

\section{INTRODUCTION}

Yuheng Mining Area [1] in China is located in the bordering area of Maowusu Desert and Loess Plateau, which is a typical desert beach area, and has been defined as a region of drought and semi drought water shortage [2] for a long time. However, water disasters in the western mining are a have occurred frequently in recent years, and have caused people to pay attention to the water-bearing stratum of this area. The existing survey and exploration data and detailed studies about Xiaojihan Coal Mine of Huadian Coal Group Company have not found or pointed out that the coal seam is the main aquifer. However, with the development of Xiaojihan Coal Mine, they found a special geological phenomenon that the mining coal seam is the main aquifer [3-5] for the first time, especially in the western shaft area. Field observation and research showed that Xiaojihan coal seam of Yuheng Mining Area was aquifer. In the process of tunnel excavation, the main source of water seepage [6] is No.2 coal seam fissure water and sandstone fissure water in coal roof, which contains more than $80 \%$ mine water inflow. The No.2 coal seam was stable, and its structure was simple. However, the fracture of this seam development well and its direct roof has a certain thickness of water resisting layer and had a good water storage space. Due to the No.2 coal seam was a high pressure aquifer, the original geologic exploration report and research report on the mine water inflow was expected to be far from the actual situation, which caused that the mining work was always in a passive state, and has a severe influence on the mine construction schedule. Based on the local geological structure and hydrological structure, the existing literature [7-9] analyzed the characteristics of the water bearing coal seam. Wuqiang [10] etcanalyzed the basic classification status and characteristics of the hydro-geological types in China's coal mines, the main water disaster problem and water prevention and control organization and safeguard measures of four main coal mining areas in China; By using transient electromagnetic 

Mine

method and integrated hydrological exploration of seismic exploration, Liu Shu-cai[11] etc improved the accuracy of coal mine water exploration; Based on the analysis of the combination of theory and experimental measurement, Ding Huan-de[12-13]studied the geological evolution law of coal measure strata, and revealed the characteristics of the geological environment of the special geological environment.

The aquifer is usually located above or below the coal seams, which rarely exists in the coal seams. Based on the special structure of "confined water storage in the No.2 main coal seam" in the Xiaojihan Coal Mine, this paper puts forward a new problem for the mine project [14].The mechanical properties of water bearing coal seams have great influence on the fracture production of coal seam[15], in relation to the production efficiency and safety of super large mine. However, the physical and mechanical properties of water bearing coal seams are different from that of conventional coal, which has special characteristics. In the paper, mechanical properties such as tensile strength and internal friction angle of water bearing coal are studied by the experiment[16-19], which provided some necessary basic data for the similar simulation and numerical simulation of the safety mining of the super large mine.

To summarize, prevention and control of water disasters and water conservation measures have a great significance in western coal mine. Yuheng Mining Area was a typical structure with shallow and thin loose sand strata-thick bedrock-coal seam bearing water. Based on the special geological conditions of Yuheng Mining Area, in this paper we analyzed geological conditions of coal seam as aquifer, and studied the mechanical characteristics of water bearing coal seam and explored the mechanism of mine water inrush.

\section{Mechanical Performance test of Xiaojihan Coal Seam}

\subsection{Sample and Test Plan}

Collecting coal (rock) from Xiaojihan coal seam, according to the test procedure requirement for physical and mechanical properties of DY-94 rock, we processed sample as the core. The sample numbers are shown in Table 1.

Table1. Sample size

\begin{tabular}{|c|c|c|c|c|c|c|}
\hline $\begin{array}{c}\text { Strata } \\
\text { No. }\end{array}$ & Rock name & $\begin{array}{c}\text { Sample } \\
\text { number }\end{array}$ & $\begin{array}{c}\text { Numbers } \\
(\text { piece })\end{array}$ & $\begin{array}{c}\text { Diameter } \\
(\mathrm{mm})\end{array}$ & $\begin{array}{c}\text { Height } \\
(\mathrm{mm})\end{array}$ & $\begin{array}{c}\text { Thickness } \\
(\mathrm{mm})\end{array}$ \\
\hline 1 & Grain arkose in luohe group & $\mathrm{C} 1$ & 15 & 50 & 100 & 25 \\
\hline 2 & Stable set of sandstone and mudstone interbed & $\mathrm{C} 2$ & 15 & 50 & 100 & 25 \\
\hline 3 & Straight set of mudstone and sandstone & $\mathrm{C} 3$ & 15 & 50 & 100 & 25 \\
\hline 4 & Yanan group leader stone sandstone & $\mathrm{C} 4$ & 15 & 50 & 100 & 25 \\
\hline 5 & Sandy mudstone yanan group & $\mathrm{C} 5$ & 15 & 50 & 100 & 25 \\
\hline 6 & Yanan leader Shi Shayan & C6 & 15 & 50 & 100 & 25 \\
\hline 7 & Sandy mudstone yanan group & C7 & 15 & 50 & 100 & 25 \\
\hline 8 & No.2 coal & C8 & 15 & 50 & 100 & 25 \\
\hline 9 & Rich county sandy mudstone & C9 & 15 & 50 & 100 & 25 \\
\hline
\end{tabular}

The mechanical properties of typical strata of BS5 hole-drilling was tested, which includes uniaxial compression, triaxial compression and split test. Though uniaxial compression tests, we can get the rock uniaxial compressive strength, elastic modulus and ratio of Poisson. Through splitting test, we can get the tensile strength of rock. Through the three axis test; we can obtain the compressive strength and the internal friction angle of the four stage confining pressure.

\subsection{Test Equipment and Principles}

Uniaxial compression test, triaxial compression test and split test were carried out by the CMT5305 electronic universal machine, as shown in Fig1. 


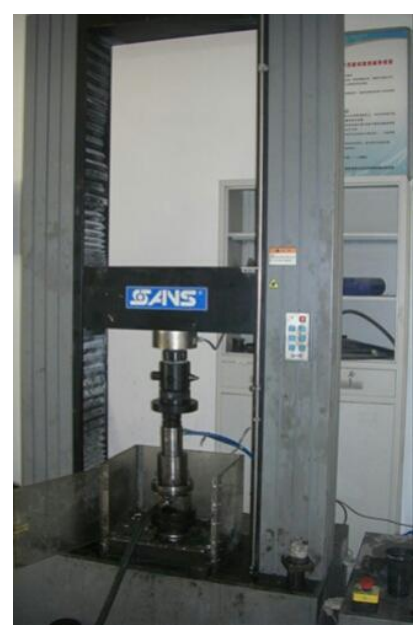

(a) CMT5305 Test Machine

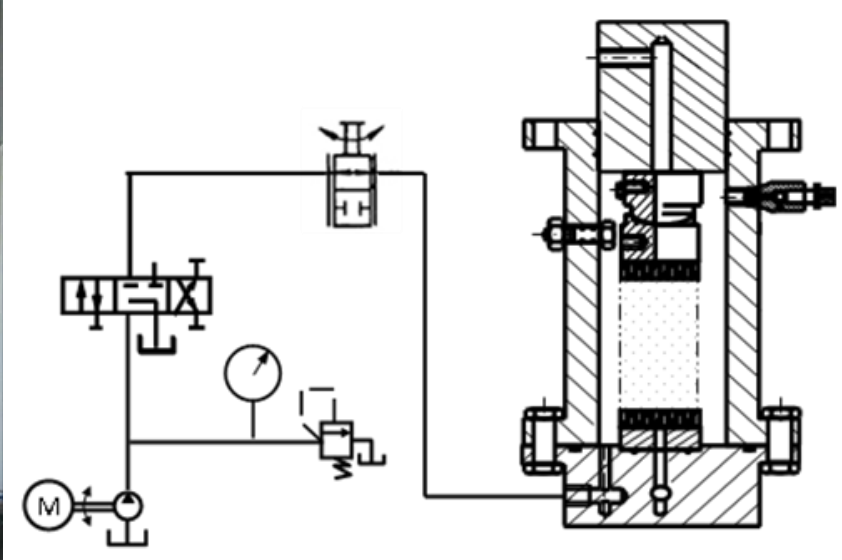

(b) Confining pressure loop

Fig1.Test system diagram

\subsection{Uniaxial Compression Test}

The uniaxial compression tests are shown as Fig 2. Measure the diameter for $d_{s}$ and height for $h_{s}$ of rock (coal) before the experiments. During the loading the system can collect the axial displacement $u_{a}$, axial load for $p$ and radial displacement $u_{r}$. We can get the axial failure load $p_{b}$ in the test data fileand according to the following formula, we can calculate the uniaxial compressive strength of rock (coal) sample for $\sigma_{c}$.

$\sigma_{c}=\frac{P_{b}}{\frac{\pi}{4} d_{s}^{2}}$
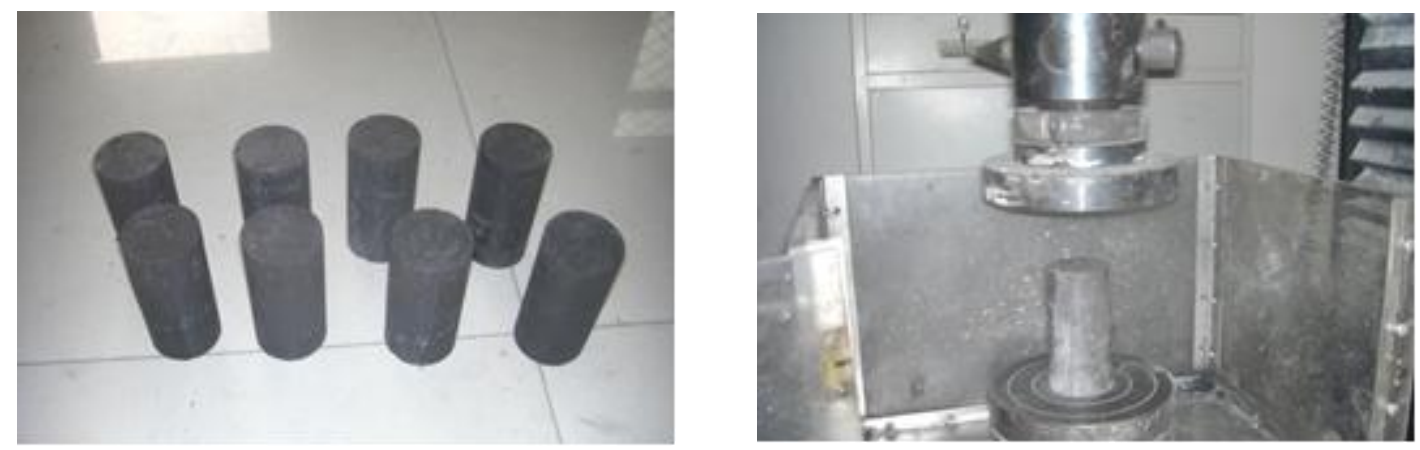

(a) Before the test
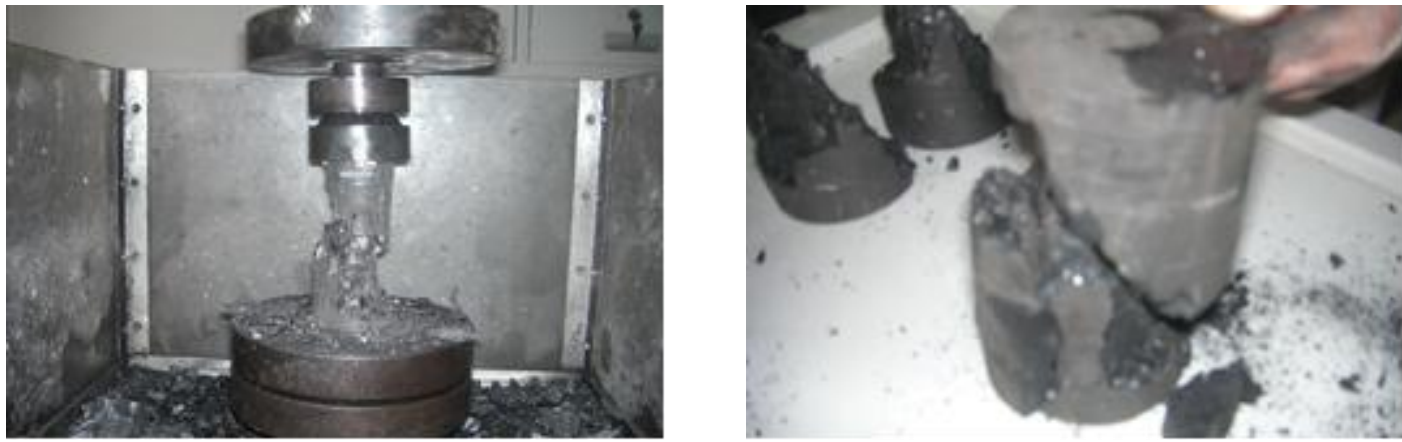

(b) After the test

Fig2. Uniaxial compression test

For every moment, axial strain, circumferential strain and axial stress can be calculated by the formula $\varepsilon_{\alpha}=\frac{u_{\alpha}}{h}, \varepsilon_{\theta}=\frac{2 u_{r}}{d_{s}}, \sigma_{\alpha}=\frac{P_{b}}{\frac{\pi}{4} d_{s}^{2}}$ respectively, sowe can draw out the axial stress-strain curves and 

Mine

circumferential strain-axial strain curves. The elastic modulus for $E$ can be calculated by the straight line slope of the axial stress-strain curve, while Poisson's ratio can be calculated by the slope of the linear segment of the circumferential strain-axial strain curve.

\subsection{Split Test}

During the testing, the concentrated load is applied along the diameter direction of the cylindrical specimen; at last the specimen is cracked along the force direction. According to the elastic mechanics formula, the rock produced approximately horizontal uniform tensile stress along the direction perpendicular to force; the average value is as follows.

$\sigma=\frac{2 P}{\pi d_{s} h_{s}}$

Where $d_{S}$ is thecore diameter, $h_{s}$ is therock height, $P$ is theload.The tensile strength of rock is

$\sigma_{t}=\frac{2 P^{*}}{\pi d_{s} h_{s}}$

Split test device is as shown in Fig 3.

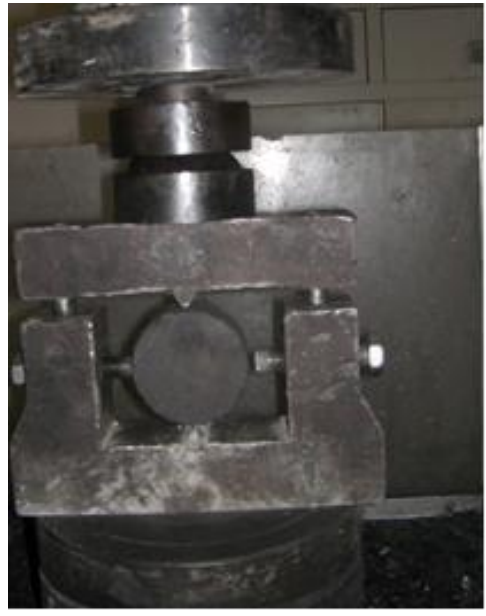

(a) Before split

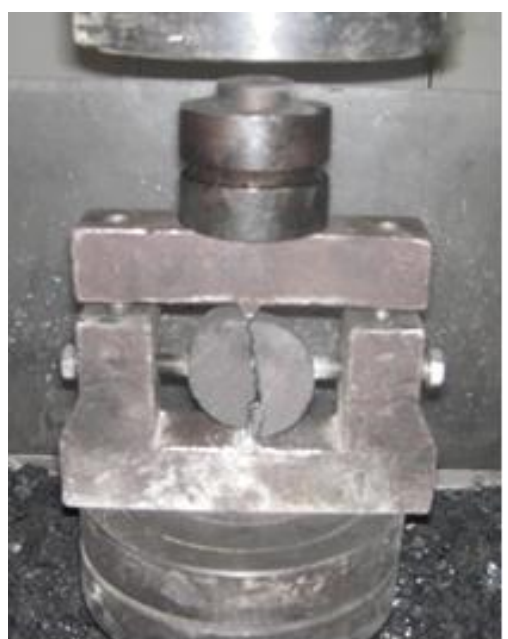

(b) After split

Fig3. Split test

\subsection{Triaxial Compression Test}

Triaxial compression test device is as shown in Fig 4.

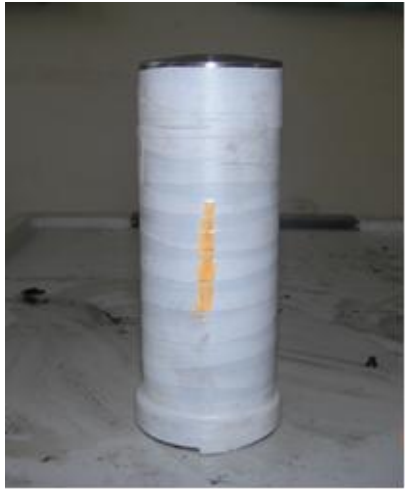

(a) Before the test

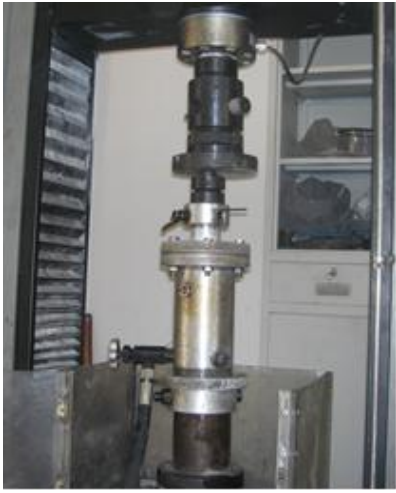

(b) During the test

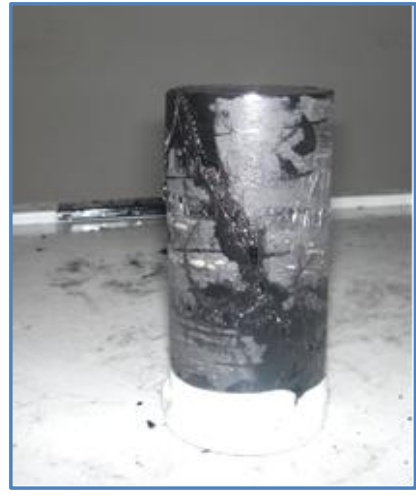

(c) After the destruction

Fig4. Triaxial compression test

The diameter $d_{s}$ and the height $h_{s}$ were measured before the test. In test, we controlledthe displacement velocity and load time and collected the axial displacement $u_{a}$ and the axial load for $P$.Thus read axial 
Experimental Study on the Mechanical Properties of Coal Seam as a Main Aquifer of Xiaojihan Coal Mine

$\operatorname{load} P_{b}$ at failure in the test data file and based on equation (1), we can calculate the compressive strength of rock.

The broken rock obeys the Mohr-Coulomb criterion, when the failure occurs, the axial stress and confining pressure satisfied

$\sigma_{1}=\frac{2 C \cos \Phi}{1-\sin \Phi}+\sigma_{3} \tan ^{2} \frac{\pi+\Phi}{2}$

Let $k_{1}=\frac{2 C \cos \Phi}{1-\sin \Phi}, k_{1}=\tan ^{2} \frac{\pi+\Phi}{2}$, we can obtain $\sigma_{1}=k+k_{1} \sigma_{3}$ by the test results and linear regression, and then can calculate the internal friction angle for $\Phi=2 \arctan \sqrt{k_{1}}-\pi$ by $k \operatorname{and} k_{1}$.

\section{TEST RESUlT}

\subsection{Compressive Strength}

The uniaxial compression tests were carried out on the cylindri calrock sample with 100-mm-height and 50-mm-diameterfrom each stratum as shown in Table 1.Thesamples number from each stratum is 5. The compressive strength, elastic modulus and Poisson ratio of the specimens were obtained by tests. Results from an average of 5 groups are shown in Table 2.Comparison curves from uniaxial compression test results of different rock stratum are shown inFig5.

Table2. Results of uniaxial compression test

\begin{tabular}{|c|c|c|c|c|c|c|}
\hline $\begin{array}{c}\text { Strata } \\
\text { No. }\end{array}$ & Rock name & $\begin{array}{c}\text { Diameter } \\
(\mathrm{mm})\end{array}$ & $\begin{array}{c}\text { Height } \\
(\mathrm{mm})\end{array}$ & $\begin{array}{c}\text { Elastic } \\
\text { modulus } \\
(\mathrm{Gpa})\end{array}$ & $\begin{array}{c}\text { Poisson ratio } \\
\text { Compressive } \\
\text { strength } \\
(\mathrm{MPa})\end{array}$ \\
\hline 1 & Grain arkose in luohe group & 50 & 100 & 1.14 & 0.36 & 17.73 \\
\hline 2 & Stable set of sandstone and mudstone interbed & 50 & 100 & 3.79 & 0.26 & 23.02 \\
\hline 3 & Straight set of mudstone and sandstone & 50 & 100 & 4.01 & 0.24 & 31.62 \\
\hline 4 & Yanan group leader stone sandstone & 50 & 100 & 2.94 & 0.26 & 42.23 \\
\hline 5 & Sandy mudstone yanan group & 50 & 100 & 1.01 & 0.28 & 21.15 \\
\hline 6 & Yanan leader Shi Shayan & 50 & 100 & 6.74 & 0.29 & 45.4 \\
\hline 7 & Sandy mudstone yanan group & 50 & 100 & 1.45 & 0.36 & 18.65 \\
\hline 8 & Rich county sandy mudstone & 50 & 100 & 1.84 & 0.34 & 20.09 \\
\hline 9 & $\quad$ No.2 coal & 50 & 100 & 0.84 & 0.18 & 10.34 \\
\hline
\end{tabular}

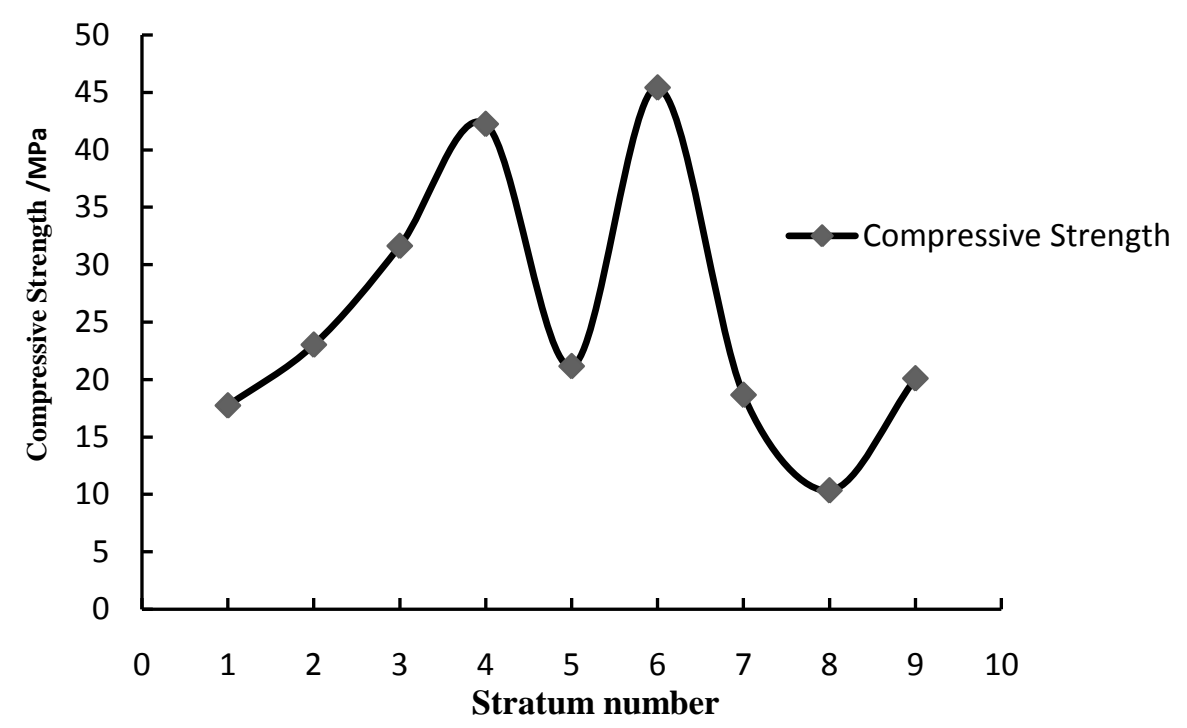

(a) Compressive strength 


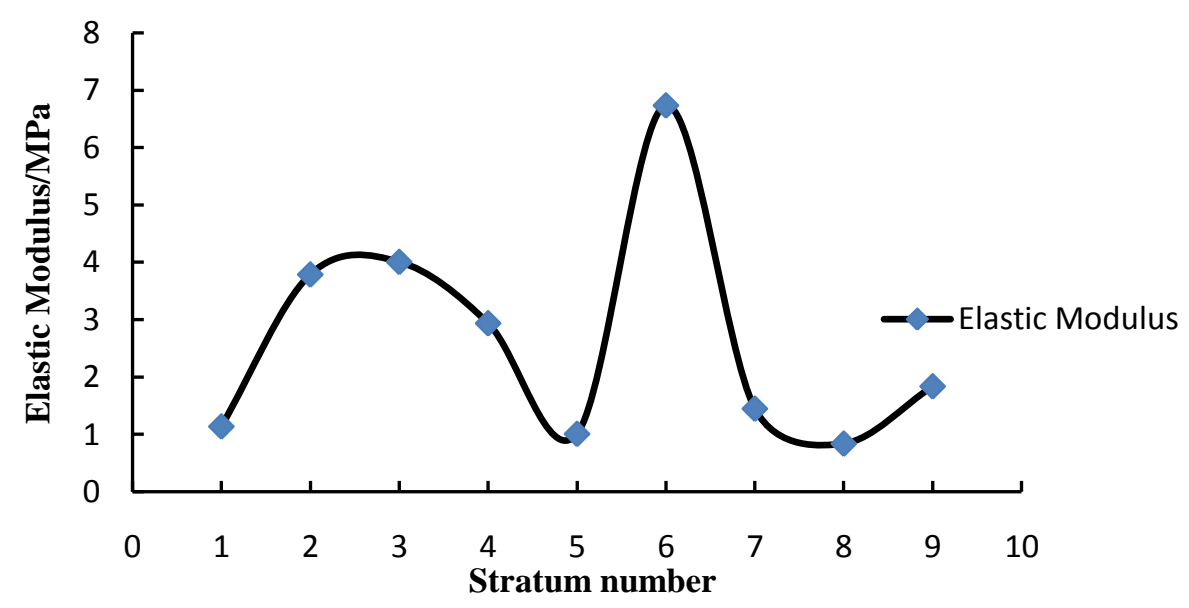

(b) Elastic modulus

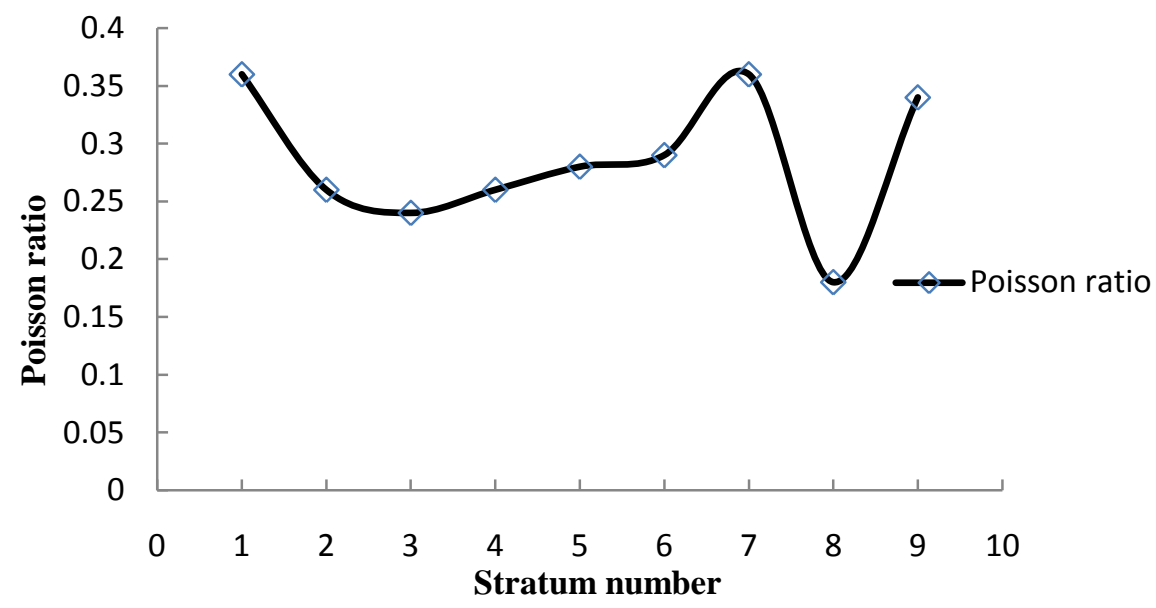

(c) Poisson ratio

Fig5. Comparison of uniaxial compression test results for different rock strata

\subsection{Tensile Strength}

The split tests were carried out on the circular-plate type rock sample with 25-mm-thick and 50-mmdiameter from each stratum as shown in Table 1.The samples number from each stratum is 5 . The tensile strength of specimens was obtained by the average of 5 groups, as shown in Table 3.Comparison curves of tensile strength of different rock stratum are shown inFig6.

Table3. Split test results

\begin{tabular}{|c|c|c|c|c|}
\hline $\begin{array}{c}\text { Strata } \\
\text { No. }\end{array}$ & Rock name & $\begin{array}{c}\text { Diameter } \\
(\mathrm{mm})\end{array}$ & Height (mm) & $\begin{array}{c}\text { Tensile } \\
\text { strength } \\
(\mathrm{MPa})\end{array}$ \\
\hline 1 & Grain arkose in luohe group & 50 & 25 & 1.62 \\
\hline 2 & Stable set of sandstone and mudstone interbed & 50 & 25 & 2.11 \\
\hline 3 & Straight set of mudstone and sandstone interbed & 50 & 25 & 3.03 \\
\hline 4 & Yanan group leader stone sandstone & 50 & 25 & 4.18 \\
\hline 5 & Sandy mudstone yanan group & 50 & 25 & 2.26 \\
\hline 6 & Yanan leader Shi Shayan & 50 & 25 & 4.31 \\
\hline 7 & Sandy mudstone yanan group & 50 & 25 & 1.83 \\
\hline 8 & & 50 & 25 & 1.27 \\
\hline 9 & Ro.2 coal & 50 & 25 & 1.92 \\
\hline
\end{tabular}




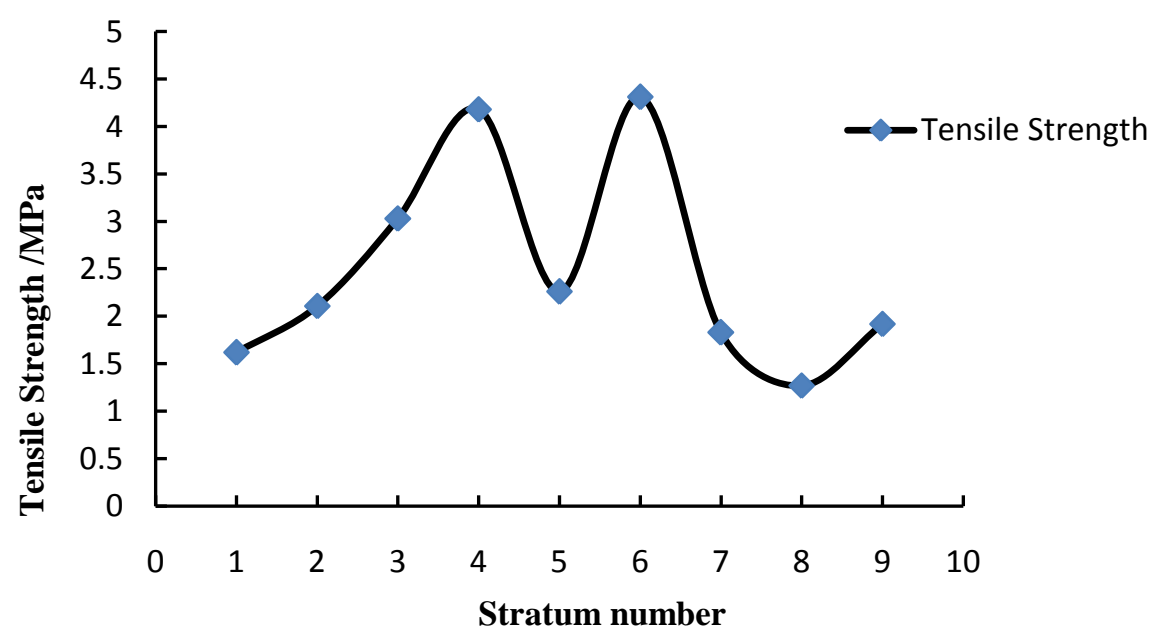

Fig6. Tensile strength curves of each stratum

Based on the research on the strength characteristics of water bearing coal seam(No.2),the compressive strength, elastic modulus, Poisson ratio (as shown in Fig. 5) and tensile strength (as shown in Fig. 6) are lower than that of the other strata, and its tension resistance ability is rather lower. This is the special physical and mechanical property which differs from the other rock stratum.

\subsection{Internal Friction Angle}

The confining pressure in triaxial compression test is set with five levels, which is divided into0MPa, $2 \mathrm{MPa}, 4 \mathrm{MPa}, 6 \mathrm{MPa}$ and $8 \mathrm{MPa}$ respectively. The test results of the internal friction angle are shown in Table 4.Comparison curves of internal friction angle for different rock stratum are shown in Fig7.

Table4.Triaxial compression test results

\begin{tabular}{|c|c|c|c|c|c|c|c|}
\hline $\begin{array}{l}\text { Strata } \\
\text { No. }\end{array}$ & Rock name & $\begin{array}{l}\text { Sample } \\
\text { number }\end{array}$ & $\begin{array}{c}\text { Diameter } \\
(\mathrm{mm})\end{array}$ & $\begin{array}{l}\text { Height } \\
(\mathrm{mm})\end{array}$ & $\begin{array}{c}\text { Confining } \\
\text { pressure } \\
(\mathrm{MPa})\end{array}$ & $\begin{array}{c}\text { Compressive } \\
\text { strength } \\
(\mathrm{MPa})\end{array}$ & $\begin{array}{c}\text { Internal } \\
\text { friction } \\
\text { angle } \\
\left({ }^{\circ}\right) \\
\end{array}$ \\
\hline \multirow[t]{5}{*}{1} & \multirow{5}{*}{$\begin{array}{c}\text { Grain arkose } \\
\text { in luohe } \\
\text { group }\end{array}$} & C1-01 & 49.37 & 100.85 & 0 & 18 & \multirow[t]{5}{*}{32.9} \\
\hline & & C1-02 & 50.24 & 101.56 & 2 & 28.5 & \\
\hline & & C1-03 & 50.82 & 99.97 & 4 & 34.5 & \\
\hline & & C1-04 & 51.08 & 100.82 & 6 & 40.2 & \\
\hline & & C1-05 & 49.8 & 101.31 & 8 & 46 & \\
\hline \multirow[t]{5}{*}{2} & \multirow{5}{*}{$\begin{array}{l}\text { Stable set of } \\
\text { sandstone } \\
\text { and } \\
\text { mudstone } \\
\text { interbed }\end{array}$} & C2-01 & 51.16 & 101.35 & 0 & 23.03 & \multirow[t]{5}{*}{32.9} \\
\hline & & $\mathrm{C} 2-02$ & 50.28 & 101.56 & 2 & 34.8 & \\
\hline & & $\mathrm{C} 2-03$ & 50.72 & 100.87 & 4 & 40.2 & \\
\hline & & $\mathrm{C} 2-04$ & 49.98 & 99.92 & 6 & 45.7 & \\
\hline & & C2-05 & 49.29 & 101.41 & 8 & 51.3 & \\
\hline \multirow[t]{5}{*}{3} & \multirow{5}{*}{$\begin{array}{l}\text { Straight set } \\
\text { of mudstone } \\
\text { and } \\
\text { sandstone } \\
\text { interbed }\end{array}$} & C3-01 & 49.37 & 99.65 & 0 & 31.95 & \multirow[t]{5}{*}{30.2} \\
\hline & & C3-02 & 49.24 & 101.56 & 2 & 34.3 & \\
\hline & & C3-03 & 50.52 & 99.87 & 4 & 41.5 & \\
\hline & & C3-04 & 51.78 & 100.42 & 6 & 47.9 & \\
\hline & & C3-05 & 51.89 & 101.41 & 8 & 55.4 & \\
\hline \multirow[t]{5}{*}{4} & \multirow{5}{*}{$\begin{array}{l}\text { Yanan group } \\
\text { leader stone } \\
\text { sandstone }\end{array}$} & C4-01 & 51.37 & 100.98 & 0 & 41.5 & \multirow[t]{5}{*}{30} \\
\hline & & C4-02 & 50.24 & 100.43 & 2 & 52.9 & \\
\hline & & C4-03 & 49.52 & 99.87 & 4 & 57.6 & \\
\hline & & C4-04 & 51.08 & 101.42 & 6 & 61.4 & \\
\hline & & C4-05 & 49.89 & 99.81 & 8 & 67.3 & \\
\hline \multirow[t]{5}{*}{5} & \multirow{5}{*}{$\begin{array}{c}\text { Sandy } \\
\text { mudstone } \\
\text { yanan group }\end{array}$} & C5-01 & 51.49 & 99.68 & 0 & 18.02 & \multirow[t]{5}{*}{30.1} \\
\hline & & C5-02 & 49.38 & 101.76 & 2 & 26.4 & \\
\hline & & C5-03 & 50.83 & 100.39 & 4 & 31.5 & \\
\hline & & C5-04 & 51.82 & 101.76 & 6 & 37.4 & \\
\hline & & C5-05 & 50.76 & 99.28 & 8 & 42.6 & \\
\hline
\end{tabular}


Experimental Study on the Mechanical Properties of Coal Seam as a Main Aquifer of Xiaojihan Coal Mine

\begin{tabular}{|c|c|c|c|c|c|c|c|}
\hline \multirow[t]{5}{*}{6} & \multirow{5}{*}{$\begin{array}{l}\text { Yanan leader } \\
\text { Shi Shayan }\end{array}$} & C6-01 & 51.24 & 99.12 & 0 & 46.2 & \multirow[t]{5}{*}{30.2} \\
\hline & & C6-02 & 49.78 & 101.38 & 2 & 53.4 & \\
\hline & & C6-03 & 50.69 & 101.59 & 4 & 59.8 & \\
\hline & & C6-04 & 51.01 & 99.46 & 6 & 65.2 & \\
\hline & & C6-05 & 50.48 & 100.28 & 8 & 70.6 & \\
\hline \multirow[t]{5}{*}{7} & \multirow{5}{*}{$\begin{array}{c}\text { Sandy } \\
\text { mudstone } \\
\text { yanan group }\end{array}$} & C7-01 & 50.35 & 101.78 & 0 & 17.82 & \multirow[t]{5}{*}{34.3} \\
\hline & & C7-02 & 51.24 & 100.49 & 2 & 26.3 & \\
\hline & & C7-03 & 49.92 & 99.79 & 4 & 35.9 & \\
\hline & & C7-04 & 50.08 & 100.02 & 6 & 38.6 & \\
\hline & & C7-05 & 49.81 & 99.87 & 8 & 47.5 & \\
\hline \multirow[t]{5}{*}{8} & \multirow[t]{5}{*}{ No.2 coal } & C8-01 & 51.23 & 100.68 & 0 & 8.89 & \multirow[t]{5}{*}{24} \\
\hline & & C8-02 & 49.88 & 101.43 & 2 & 9.2 & \\
\hline & & C8-03 & 50.13 & 100.48 & 4 & 14.6 & \\
\hline & & C8-04 & 50.81 & 100.74 & 6 & 19.8 & \\
\hline & & C8-05 & 51.76 & 101.28 & 8 & 27.3 & \\
\hline \multirow[t]{5}{*}{9} & \multirow{5}{*}{$\begin{array}{l}\text { Rich county } \\
\text { sandy } \\
\text { mudstone }\end{array}$} & C9-01 & 51.04 & 99.66 & 0 & 19.6 & \multirow[t]{5}{*}{35.1} \\
\hline & & C9-02 & 49.78 & 100.31 & 2 & 28.6 & \\
\hline & & C9-03 & 50.69 & 101.45 & 4 & 38.5 & \\
\hline & & C9-04 & 49.91 & 100.46 & 6 & 42.6 & \\
\hline & & C9-05 & 50.48 & 100.28 & 8 & 49.7 & \\
\hline
\end{tabular}

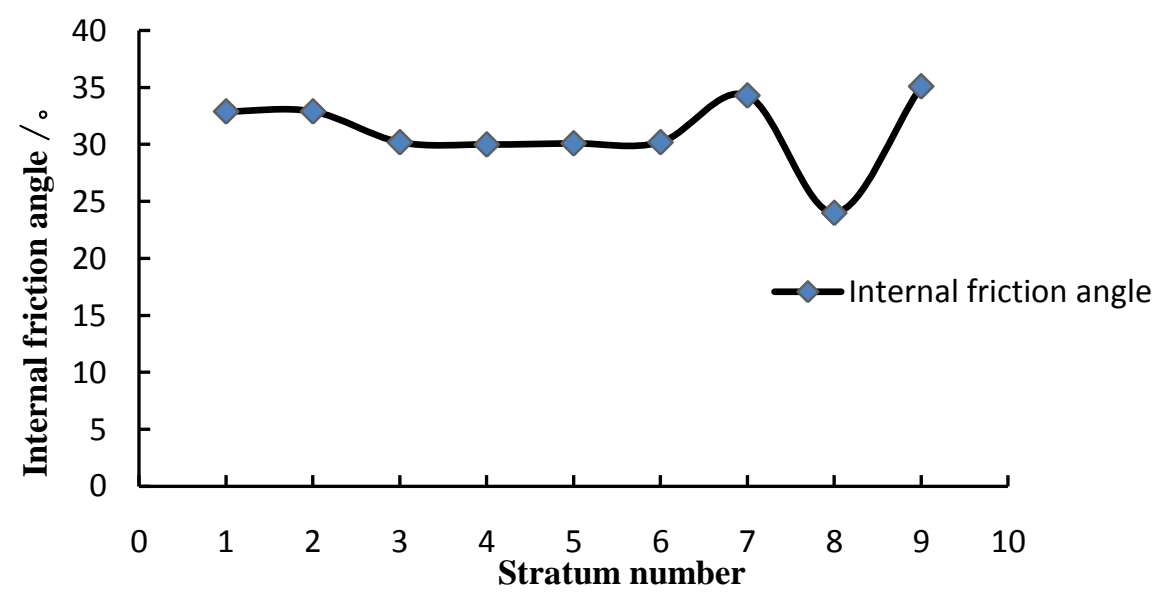

Fig7. Comparison of the internal friction angle for different rock layers

It can be seen from Fig7 that the internal friction angle of other strata is normal, while this angle of theNo.2 coal seam is small, which explained that the fracture of the No.2 coal seam is not easy to close. The internal friction angle of the other adjacent rock stratum located at the up or down coal seam is large, so the fracture is easy to close; therefore, water in the No.2 coal seam streams (or flows)hard up and down. This is also an important reason for the No.2 coal seam is the main aquifer.

\section{CONCLUSiOnS}

By CMT5305 Testing Machine, the experiments including uniaxial compression, split, triaxial compression were carried out to the rock (coal) sample from the Xiaojihan coal mine.Asa result, we obtained some mechanical properties of the test rock from the coal seam being the main aquifer of Xiaojihan Coal Mine. Research shows:

1) Differing from the common rock seam, the special physical and mechanical characteristics of the water bearing coal seam(No.2) is that its compressive strength, modulus of elasticity, Poisson, tensile strength and internal friction angle were lower than that of the other rock strata. Compared with the geological and hydrological structure of coal seam, the mechanical properties are more suitable to describe the characteristics ofNo. 2 coal seam as main aquifer.

2) An important reason for coal seam containing water is that the internal friction angle of coal seam, by contrast, is too small for its fracture to close easily. 

Mine

3) By studying the mechanical properties such as tensile and internal friction angle of water bearing coal seam (No.2), a reliable theoretical basis can be provided for predicting the working face in coal mine and the mine discharge, for establishing an early warning system about water disaster in mine, for designing and optimizing the technology in tunneling and coal mining about the flood preventing and controlling.

\section{REFERENCES}

[1] Y B Tang, LJ Zhai, Y J Fu, X F Ma, Q M Li, Z XLi,RZhang, (2012)Classification of hydro-geological types of coal base planning in China, Chinese Coal Geological Exploration,09:28-32+49.

[2] X X Miao, AWang, Y JSun, L G Wang, HPu, (2012) Research on basic theory of mining with water resources protection and its application to arid and semi-arid mining areas. Chinese Journal of Rock Mechanics and Engineering, 09:28-32+49.

[3] X X Miao,X B Mao, Z W Sun, HPu, (2005)Formation conditions of compound key strata in mining over layer strata and its discriminance. Journal of China University of Mining and Technology,05:547-550.

[4] X Z Wang, J L Xu, W B Zhu, (2014) Study on the influence of the characteristic of unconsolidated confined aquifer on its property of load transfer. Journal of Mining and Safety Engineering,499-505.

[5] H BBai, X XMiao, (2009) Research progress and major problems of water preserved coal mining. Journal of mining and safety, 253-505.

[6] H W Qian, (2015) Study on the Deformation Mechanism of Water-rich Coal Roadway of Xiaojihan Coal Mine". China University of Mining and Technology.

[7] B MLiu, (2012) Study on the method of hydrogeological control and productivity potential assessment of coal seam gas exploitation. China University of Mining and Technology (Beijing).

[8] Y LLiu, (2014) Study on the Key Factors of Water Inrush during Mining under the Unconsolidated Confined Aquifer of Hydrogeology and Engineering Geology. An Hui University of Science Mid Technology.

[9] H Z Shen, (2005) Study on the hydrogeological characteristics of the fourth aquifer in the SuNan mining area. AnHui University of Science Mid Technology.

[10] Z W Zhang, QWu, E JFu, Z L Fan, (2011)Coal seam roof and floor hydrogeology conditions evaluation of PingshuoNo.1 mine and measures of preventing water bursting. Engineering Science in China, 11:94-101.

[11] S CLiu, (2008) Mechanism of water inrush from coal seam floor and continuous survey of fractured zones in coal seam floor. China University of Mining and Technology.

[12] H D Ding, Z MMao, QHe, (2014) the hydrogeologic feature of Yuheng coal and its influence on research of coal seam mining. Mining Technology, 03: 92-95.

[13] H D Ding, RGAO, QHe, (2014) Research on Safe and Efficient Road way Excavation. Technology of main aquifer coal seam. Mining research and development, 03: 38-40+69.

[14] L Zhu, (2007) Several Simple Methods of Observing Quantity of Water Gush. Coal Technology, 01:86-87.

[15] STao, Y B Wang,D N Tang, HXu, WHe, Y Li, (2012) Pore and Fracture Systems and Their Contribution to the Permeability of Coal Reservoirs in Southern Qinshui Basin. Geological Journal of China Universities, 03:522-527.

[16] JXu, X F Xian, Y G Du, G Y Zhang, (1993)An Experimental Study on the Mechanical Property of the Gasfilled Coal. Journal of Chong Qing University, 05:42-47.

[17] PLu, Z W Sheng, G W Zhu, E C Fang, (2001) The Effective Stress and Mechanical Deformation and Damage Characteristics of Gas-filled Coal. Journal of University of Science \& Technology China,06: 5562.

[18] P D Sun, X XXian, Y MQian, (1999) Experimental study on the law of effective stress of coal. Mining safety and environmental protection, 02:16-18+49.

[19] CH Zhang, (2010) Simulation Experiment on the Mechanical Characteristics during out Bursting Coal Seam Uncovered by Crosscut. Anhui University of Science and Technology.

\section{AUTHORS' BIOGRAPHY}

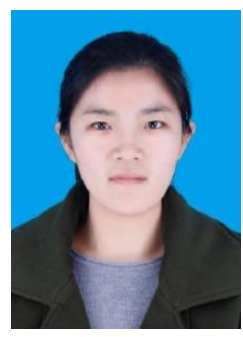

Jingna Guo, is currently studying for a master's degree at China University of Mining and Technology. Her main research topics are Seepage mechanics of rock mass. 

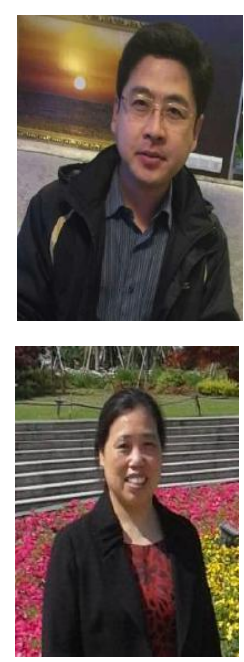

Qiang Li, is a Lecturer works in China University of Mining and Technology. He received Bachelors, Masters and Ph.D. degrees in Engineering Mechanics from China University of Mining and Technology. His current research topics are Seepage mechanics of mining rock mass.

Shun-cai Li, is a Professor of Jiangsu Normal University. She received a bachelor's degree in engineering mechanics from Chongqing University in 1991, a master's degree and a doctoral degree in engineering mechanics from China University of Mining and Technology in 2000 and 2006 respectively. Her current research topics are Seepage mechanics of mining rock mass.

Citation: Jingna Guo et al. (2017). Experimental Study on the Mechanical Properties of Coal Seam as a Main Aquifer of Xiaojihan Coal Mine, International Journal of Mining Science (IJMS), 3(4), pp.24-33, DOI: http://dx.doi.org/ 10.20431/2454-9460.0304003.

Copyright: ( 2017 Jingna Guo. This is an open-access article distributed under the terms of the Creative Commons Attribution License, which permits unrestricted use, distribution, and reproduction in any medium, provided the original author and source are credited 